\title{
Constructing Views of Science Tied to Issues of Equity and Diversity: A Study of Beginning Science Teachers
}

\author{
Julie A. Bianchini, Eric M. Solomon \\ Department of Education, University of California, Santa Barbara, California 93106-9490
}

Received 8 January 2002; Accepted 5 August 2002

\begin{abstract}
In this study, we examined the discursive and social practices of a teacher educator (the first author) and her eight beginning science teachers in a course on the nature of science and issues of equity and diversity. We focused our investigation on beginning science teachers' views of science and science teaching, as well as the grounds they offered for their views. We organized our discussion of the nature of science, teacher learning, and grounds for views along three dimensions: personal, social, and political. We found that beginning teachers routinely drew from only one of these three dimensions to support their views of the nature of science and ways to represent science to all students. In our implications, we recommend that teacher educators encourage teacher learners to examine personal, social, and political grounds carefully and critically in the process of constructing or revising their views. We argue that attention to these three dimensions of grounds for views will assist beginning teachers in adopting nature of science positions that are broad and complex, that more clearly reflect the goals of equity and excellence, and thus, that hold greater promise for achieving a science education inclusive of all students. (C) 2003 Wiley Periodicals, Inc. J Res Sci Teach 40: 53-76, 2003
\end{abstract}

I think this class [on the nature of science and issues of equity] broadened [my view of science] and complicated that [view]. Just like, What is science? I have a better idea [now how to answer that], but also more questions about what science is and where the borders [between science and other disciplines are]. (Bo, preservice science teacher, end of course interview, 12.19.99) ${ }^{1}$

To promote scientific literacy for all, science education reform documents recommend that teachers teach the nature of science-that they portray science as a human activity with particular methods of inquiry, collective criteria for knowledge claims, and diverse ties to the larger society [American Association for the Advancement of Science (AAAS), 1989, 1993; National Research Council (NRC), 1996]. An increasing number of science educators, however, call for

Correspondence to: J.A. Bianchini; E-mail: jbianchi@education.ucsb.edu DOI 10.1002/tea.10060

Published online in Wiley InterScience (www.interscience.wiley.com). 
descriptions of the nature of science found in reform documents to be broadened and complicated even further; they suggest teachers draw from recent science studies scholarship to craft descriptions of science that attend to issues of gender and race, positionality and context, and power and privilege (Cunningham \& Helms, 1998; Mayberry, 1998; Richmond, Howes, Kurth, \& Hazelwood, 1998; Rudolph, 2000; Stanley \& Brickhouse, 1994, 2001). These latter calls to refashion nature of science descriptions in light of equity and diversity goals can be understood to be part of a larger movement to eliminate inequitable science education practices and to implement gender-sensitive and culturally inclusive strategies in their stead (Atwater, 1996; Barton, 1998, 2000; Hodson, 1999; Lynch, 2000; Nieto, 1999; Rosser, 1997; Sleeter \& Grant, 1999).

In our ongoing work with beginning science teachers, we use feminist and other science studies scholars' accounts to shape our definition of the nature of science. We believe beginning science teachers must examine science studies scholars' claims and integrate such scholarship into their views of science if they are to implement educational practices that make science interesting and understandable to all students. Of course, we recognize that connections among the ideas conveyed to beginning teachers, the views they construct, and the strategies they ultimately implement are far from direct. Researchers have found that beginning teachers do not necessarily learn those aspects of the nature of science taught to them (Abd-El-Khalick, Bell, \& Lederman, 1998) or translate their views of science into their instructional practices (Brickhouse \& Bodner, 1992). Still, we remain convinced that a first and necessary step to enacting an equitable and excellent science education is for teacher educators to present the nature of science as a multilayered and at times contested body of knowledge to beginning teachers - to encourage beginning teachers to use science studies scholarship to broaden and complicate their views of science and science teaching. As such, the research reported here examines the mis/connections between what a cohort of beginning teachers was taught about the nature of science and what they learned; we describe beginning teachers' successes and struggles in integrating these often unfamiliar images of science into their views. [In other papers, we explore the second step: the translation of beginning teachers' views of science into their instructional practices. See, for example, Bianchini, Johnston, Oram, \& Cavazos (in press)]. Our purpose is to provide ourselves and other science teacher educators with a deeper understanding of the grounds beginning teachers use to reinforce or revise their views of science and science teaching, and thus, with a larger number of strategies to help beginning teachers grasp the nature of science as a complex and tentative construct with direct ties to teaching science to all students.

More specifically, in this study, we examined the discursive and social practices of a teacher educator (the first author) and her 8 beginning science teachers ( 6 preservice and 2 practicing $)^{2}$ in a course on the nature of science and issues of equity and diversity. We videotaped each class session to document the knowledge and strategies this science teacher educator made available to her students, and the ideas and practices these beginning teachers took up or pushed aside in deciding how to promote scientific literacy for all. We qualitatively analyzed beginning teachers' views of science and suggested ways to represent science to all students, as well as the basis, or grounds, they offered for positions maintained. We paid particular attention to beginning teachers' attempts to both examine and construct complex, multilayered arguments for views of science and approaches to science teaching. In our implications, we identified ways to improve the education of science teachers: We discussed how greater attention to the grounds beginning teachers use to support their views can inform our own and other teacher educators' work.

Three studies in which teacher educators interrogated their own teaching of the nature of science and/or equitable educational practices resonate with our purpose and research design. These studies make clear that learning to view science and science teaching through the lens of 
equity is a complex and challenging task. Richmond et al. (1998) integrated feminist critiques of the nature of science and activities that allowed preservice teachers to explore their own relationships with science into their science methods courses. Despite Richmond and colleagues' efforts to promote critique and connection, however, teacher participants found it difficult to use feminist accounts of science to broaden their views of effective and inclusive teaching practices. Using complementary theoretical lenses, Rodriguez (1998) and Southerland and Gess-Newsome (1999) drew from theories of learning as construction to develop approaches to teaching science as equitable and inclusive. Rodriguez merged theories of social justice with those of social constructivism to craft a model of teaching and learning science he termed sociotransformative constructivism; Southerland and Gess-Newsome drew from multicultural frameworks and views of learning as personally and socially constructed to develop a social-objective constructivist approach. Again, despite implementation of these models in their methods courses, both sets of researchers found that preservice teachers remained resistant to ideological and pedagogical transformation. We return to these two themes-the importance of integrating descriptions of science with issues of equity and the need to view teacher learning through a constructivist lensin our Conceptual Framework section below.

\section{Competing Definitions of the Nature of Science}

As stated above, science education reform documents such as Science for All Americans (AAAS, 1989) and the National Science Education Standards (NRC, 1996) put forth descriptions of the nature of science agreed upon by members of the science education community and deemed appropriate for examination by Grade Kindergarten through $12(\mathrm{~K}-12)$ students. Some science education researchers see these consensus documents as providing a clear directive to teacher educators and science teachers; they have identified a coherent set of nature of science tenets important for both teachers and students to master (Abd-El-Khalick et al., 1998; Abd-El-Khalick \& Lederman, 2000a, 2000b; Bell, Lederman, \& Abd-El-Khalick, 2000; Smith, Lederman, Bell, McComas, \& Clough, 1997). Other science educators think such a list of tenets inadequate (Brickhouse, Dagher, Letts, \& Shipman, 2000; Driver, Leach, Millar, \& Scott, 1996; Stanley \& Brickhouse, 1994, 2001). Like scientific knowledge itself, this second group of science educators argues, the nature of science includes concepts and principles widely agreed upon by members of the scientific, science studies, and science education communities, as well as ideas and arguments that remain open to debate. Like scientific knowledge itself, these educators continue, our descriptions of the nature of science have and should continue to change in light of new questions, methods, and findings. Those aspects of the nature of science that have been agreed upon and those that remain contested, they underscore, should be shared with preservice and practicing teachers and to a lesser extent, their $\mathrm{K}-12$ students. In other words, the nature of science is and should be presented as complex and contested terrain.

We position ourselves within this latter group. We also think that teachers and students should be made of aware of nature of science debates and appreciate the messiness of nature of science constructs. Furthermore, we join with those science educators interested in equity issues to recommend that descriptions of the nature of science be revised to more clearly reflect disparities in access to and success in science (Cunningham \& Helms, 1998; Mayberry, 1998; Richmond et al., 1998; Rudolph, 2000; Stanley \& Brickhouse, 1994, 2001). We argue that beginning teachers must construct nature of science views tied to equity concerns if they are to make science interesting and understandable to their own students. Again, the purpose of our study is to closely examine the reasons beginning teachers offer for their views of science and science teaching, and to identify ways teacher educators can help them better align these views with equity issues. 


\section{Conceptual Framework}

We drew from two bodies of scholarship to craft our research questions and frame our analyses: science studies scholars' descriptions of science, and constructivists' accounts of teacher learning. Both science and learning, we argue, can be understood as personal, social, and political activities; we fashioned our discussions of science and teacher learning along these three lines to both highlight and attempt to make sense of their complexity. We recognize, of course, that distinctions among the personal, social, and political are somewhat artificial. In particular, we understand the personal and social dimensions of science and learning to shade into their political dimensions as well (Noffke, 1997). Still, we found these three dimensions useful in highlighting connections between descriptions of the nature of science and theories of teacher learning, as well as in interpreting our data on beginning teachers' views. We examine each body of scholarship in turn.

\section{Science as Personal, Social, and Political Activity}

We used the work of feminist science studies scholars and sociologists and anthropologists of science to fashion a description of scientific processes and products tied to issues of equity and diversity. A growing number of educators have argued that such scholarship must inform descriptions of science if teachers are to interest and engage female students and students from underrepresented ethnic groups usually positioned on the margins of the science classroom (Cunningham \& Helms, 1998; Mayberry, 1998; Richmond et al., 1998; Rudolph, 2000; Stanley \& Brickhouse, 1994, 2001). To make visible the complexity in views recommended, we organized science studies scholars' accounts along the three dimensions, or themes, discussed above: science as a personal, social, and political activity. These themes and the specific examples we present below were examined in the nature of science course under study. [Readers should note that the instructor and her beginning teachers reviewed additional nature of science documents not discussed here, for example, Science for All Americans (AAAS, 1989), the National Science Education Standards (NRC, 1996), and Teaching about Evolution and the Nature of Science (National Academy of Sciences, 1998).]

Some science studies scholars investigate the personal dimension of science-the lives and work of women scientists and scientists from underrepresented ethnic groups in disciplines primarily populated by White men (Hine, 1993; Kass-Simon \& Farnes, 1990; Keller, 1977, 1983, 1997; Rossiter, 1982, 1995; Sands, 1993; Scheich, 1997; Schiebinger, 1989). Keller (1977), for example, described her own painful transformation from an isolated woman graduate student in physics to a successful molecular biologist and feminist science studies scholar. She argued for greater recognition of the fundamental conflict between the identities of woman and scientist, as well as for greater awareness of the ways science has been structured to privilege the needs, interests, and ideas of White men. Keller (1983) also composed a biography of Barbara McClintock, a Nobel prize-winning plant geneticist who enjoyed success and endured marginality throughout her career because both her research methodology and gender differed from the norm. McClintock's respect for difference and complexity, her "feeling for the organism," was a view of scientific practice not shared by most of her colleagues. To complicate matters, Keller continued, McClintock's identity as a woman scientist clashed both with the reality that most other geneticists were men and with the view that scientific inquiry was best described as a marriage between masculine mind and female nature.

Other science studies scholars craft detailed accounts of science as a social activity, investigating the day-to-day practices of scientists to understand how they induct new members 
into their community; generate research questions, methods, and findings; and make collective decisions about the veracity of knowledge claims (Collins \& Pinch, 1993; Knorr-Cetina, 1999; Latour \& Woolgar, 1986; Lawrence \& Shapin, 1998; Shapin, 1996; Traweek, 1993). In the nature of science course, to better understand science as a fundamentally social activity, beginning teachers examined the work of Collins and Pinch (1993). Drawing from history, Collins and Pinch argued that Louis Pasteur's defeat of proponents of spontaneous generation was neither as straightforward nor as expedient as is often believed. Pasteur's success rested in large part on the support of influential colleagues - in combination with experimental luck and unwavering theoretical commitments. More recently, they continued, the physics community's decision to reject evidence of gravitational radiation extended beyond theoretical and experimental grounds to include assessment of the scientist's reputation, the size and prestige of his university of origin, and his previous history of failures.

Still other science studies scholars situate science in its larger historical, cultural, and political contexts. They document how androcentric and ethnocentric biases have constrained scientific research questions, methods, and findings (Haraway, 1989, 2000; Hubbard, 1990; Keller, 1985; Schiebinger, 1999; Spanier, 1995), or raise epistemological questions about whose practices and products have been counted as science (Barad, 1996; Dalmiya \& Alcoff, 1993; Harding, 1994, 1998; Hart, 1999; Longino, 1990; Narayan, 1989; Tuana, 1995; Weatherford, 1993). Beginning teachers in the course under study read Harding's (1994) critique of traditional conceptions of science as acultural and universal. Drawing from postcolonial studies, she argued that the modern sciences be viewed not as transcending culture, but rather as having multicultural roots and embodying distinctively Western values and beliefs. Approaching the same issue from the vantage point of marginalized knowledge systems, Dalmiya and Alcoff (1993) called for traditional women's ways of knowing, like midwifery, to be perceived as legitimate scientific practices. Weatherford (1993) suggested that the Andean Indians' work to domesticate the potato be understood as agricultural experimentation.

\section{Teacher Learning as Personal, Social, and Political Activity}

Descriptions of science as embedded in personal, social, and political contexts complement theories of teacher learning as personal, social, and political activity [see Putnam \& Borko (2000) for an overview of teacher learning research]. On a personal level, beginning teachers are understood to enter teacher education programs with prior knowledge, beliefs, and experiences that they then use to make sense of new ideas and educational practices (Feiman-Nemser \& Remillard, 1996; Hewson, Tabachnick, Zeichner, Lomker, Meyer, Lemberger, et al., 1999). Teacher learners' life-worlds - the norms, values, beliefs, expectations, and conventional actions that they bring from their home culture to a teacher education program-can harmonize or clash with the world of school, making learning to teach more or less cognitively difficult. [Here, we extend Aikenhead and Jegede's (1999) description of student learning to teacher learning. See also Costa (1995) and Jegede (1997)]. When the culture of school resonates with beginning teachers' life-worlds, borders between these two cultures are smoothly crossed and meaningful learning is easily accomplished. When the school and life-world cultures are at odds, however, beginning teachers may feel forced to abandon or marginalize their life-world concepts in favor of new ways of understanding. Border crossings become hazardous and alienation from either their life-world or from school may result. In these latter instances, teacher educators must provide teacher learners strategies to productively manage cognitive conflicts and thus, cross cultural borders with ease so that some form of collateral learning can occur. [For further discussion of teachers' worldviews, see Lee and Fradd (1998) and Lynch (2000).] 
Teachers as learners construct new knowledge not only individually, but through social interactions as well. They engage in an ongoing interchange of perspectives and ideas through which they construct and reconstruct meaning [taken from descriptions of student learning of science by Solomon (1987)]. Through multiple zones of proximal development (Vygotsky, 1978), with the help of more knowledgeable peers, a teacher learner can move toward higher levels of competence. Equally important, learning to teach requires enculturation into a larger community of practice with its distinct values, conceptual schemes, and patterns of activity. Attention to the social nature of learning suggests the need to introduce teacher learners to the unique discourse practices of the education community (Lemke, 1990; McGinn \& Roth, 1999). It also suggests the need for teacher educators, natives of the school community, to act as guides or translators between the cultures of school and teacher learners' daily lives. A teacher educator, for example, should encourage beginning teachers to make connections between their own experiences and the knowledge presented in preservice courses, as well as to make decisions about when a particular theoretical lens or instructional strategy is appropriately employed (Aikenhead, 1997; Driver, Asoko, Leach, Mortimer, \& Scott, 1994; Solomon, 1994).

Teachers' construction of new knowledge can also be considered political because it takes place in a context created by social and economic class, religion, geographic location, gender, race, and ethnicity [Rodriguez, 1998; Southerland \& Gess-Newsome, 1999; as tied to student learning, see also Nieto (1999) and O'Loughlin (1992)]. Several advocates of sociocultural constructivism use language to make visible the ways learning is shaped by differential access to power and prestige. Both O'Loughlin (1992) and Rodriguez (1998) argued that in classroom conversations, more than an individual's voice is heard and more than his or her views, conveyed. Voices, or more broadly languages, they explained, carry with them multiple meanings because they are embedded in cultural, historical, and institutional contexts and are associated with distinct patterns of authority, power, and privilege. To provide more equitable opportunities for learning, O'Loughlin recommended that teachers (or in our case, teacher educators) attempt to understand their students' own languages, as well as to introduce them to the powerful discourses of conventional disciplines like science. Rodriguez called for using language to "de/construct the structures of power from which established cultural, historical, and institutional contexts spring" and to "provide spaces where existing contexts can be collaboratively transformed to meet social justice goals" (p. 599). In part, because of connections between language and issues of power and privilege, we decided to focus our study on teacher educator and beginning teachers' discourse related to views of the nature of science and ways to represent science to all students.

\section{Research Design}

\section{Research Methodology and Questions}

This study is part of a larger, multiyear project that follows beginning science teachers from their experiences in preservice education courses through their first years of teaching science in public secondary school classrooms [see Bianchini et al. (in press) and Bianchini, Cavazos, \& Rivas (2002)]. To collect and analyze the data reported here, we employed action research methods (Elliott, 1991; Kemmis \& McTaggart, 1988; Noffke, 1997; Schon, 1991). We consider this study an example of action research because the first author taught the nature of science course under investigation, and because findings generated will be used to redesign both the course and methods selected to investigate it. A strength of action research is its long ties to the development of more democratic forms of education; at least among some of its advocates and practitioners, action research is viewed as political activity (Noffke, 1997). Similar to science educators working 
toward a more excellent and equitable science education, practitioners of action research can be understood to interrogate, critique, and attempt to alter arrangements in schools that perpetuate systemic inequities (Carr \& Kemmis, 1986; Weiner, 1989; Whyte, 1986; Zeichner, 1993). Another strength of action research is its potential to contribute to the development of a knowledge base for teaching (Noffke, 1997). As such, careful documentation of practices in a preservice course can not only provide the individual instructor with opportunities for inquiry, self-reflection, and growth (Schon, 1991), it can serve as a case for other teacher educators to use to reflect, theorize, and ultimately act to improve their own teaching (Elliott, 1991; Stenhouse, 1983).

Informed by our Conceptual Framework and research methodology, we crafted three sets of questions to guide our examination of the moment-by-moment interactions of a science teacher educator and her beginning science teachers in a course on the nature of science and issues of equity and diversity. Research questions examined teacher learners' views about what science is and how it can be taught to all students, as well as the grounds they offered for their views. One, what opportunities did the teacher educator make available to her beginning teachers to learn about the nature of science and equity issues? In turn, what views of science and ways to represent science to all students did beginning teachers share, revise, and/or construct as they discussed readings and completed activities in this nature of science course? Two, what reasons, or more broadly, grounds, did beginning teachers offer to support their views? Did these grounds reflect the complex and multilayered nature of science and science teaching? Were these grounds personal (their own experiences), social (conceptions of teaching and learning as co-constructed activities), and/or political (descriptions of school or science as historically and culturally situated) in nature? Three, how did grounds for views shape beginning science teachers' attempts to understand, negotiate, and reach consensus on ideas and strategies found at the intersection of descriptions of science and issues of equity and diversity? What questions or insights arose in the context of small group activities and whole class discussions?

\section{Setting, Beginning Teachers, and Researchers}

This study was conducted during the fall semester of the 1999-2000 academic year in a small, fifth-year teacher education program known for its attention to innovation and equity. Located in California, this program offers candidates a Single Subject Teaching credential and a masters degree in education. Its stated mission is to produce informed and reflective teacher leaders. Issues of equity and diversity are both addressed in add-on courses and infused through the standard teacher education curriculum [see Southerland \& Gess-Newsome (1999)]: Candidates are required to attend two Crosscultural, Language, and Academic Development courses and two multicultural education courses, as well as examine issues of equity and diversity in their subjectspecific methods courses. As part of their teacher education experience, the preservice teachers who participated in this study were enrolled in three closely connected science education courses: one on the nature of science in science education, a second on science methods and procedures, and a third on professional issues within the context of their school placements.

The nature of science course was the focus of this study. The course met for 3 hours each week for a total of 10 weeks. Its purpose was threefold: to introduce recent scholarship in science studies and the nature of science in science education; to encourage the making of connections between accounts of science and issues of equity and diversity; and to allow exploration of curriculum materials and instructional strategies useful in teaching science to all secondary students. Findings from a previous study (Bianchini et al., 2002) had been used to reorganize the course around three central questions: What is science? Why teach scientific content and processes to students? And, how best convey what science is and how it is practiced to all students, particularly those from 
underrepresented groups? Beginning teachers read and discussed national reform documents and the specific examples of science studies scholarship presented in the first section of our Conceptual Framework. They also participated in nature of science activities and designed content-specific lessons in small group and whole class settings. (Specific activities will be discussed in our Results section below.) Finally, teacher learners completed four individual assignments as part of their coursework: an initial opinion piece on what science is; a case study of a nature of science lesson they taught; a research-based paper on contemporary descriptions of science and ways to represent science to all students; and an end-of-semester interview conducted by the instructor. For each assignment, they were asked to address the course's three organizing questions of what, why, and how.

All beginning teachers enrolled in the nature of science course during the 1999 fall semester agreed to participate. Each brought collective and unique experiences to course activities and assignments. All eight held undergraduate degrees in the sciences and at least a 3.0 upper division grade point average. Indeed, five of the participants—Joe, Donny, Bo, Arnold, and Samantha ${ }^{3}$ had earned their undergraduate degrees at the same institution (the site of the teacher education program). Six-Jim, Joe, Donny, Bo, Reggie, and Arnold-were single-subject preservice teachers in the teacher education program. The other two, Travis and Samantha, were practicing science teachers who had taken time off from teaching to pursue masters degrees in education. Travis and Samantha had already earned their teaching credentials and had taught in secondary science classrooms for 1-3 years. Five of the eight—Jim, Joe, Donny, Bo, and Travis-were European American males. Arnold was Korean American, having immigrated to the United States when young; Reggie was Latino; and Samantha was a Japanese American female. (See Table 1.)

As individuals, Jim was the only participant to have come directly from an undergraduate science program. That spring, he had earned his anthropology degree from another campus in the state's university system. Arnold, a nontraditional student, had worked for 10 years as a lab technician before returning to the university to earn his undergraduate degree in the geological sciences. He had been employed for a short time as an assistant field geologist in a local consulting firm before deciding to pursue his teaching credential. Like Arnold, Samantha had earned her undergraduate degree in the geological sciences. She had obtained her teaching credential while

Table 1

Overview of beginning teachers enrolled in nature of science course

\begin{tabular}{|c|c|c|c|c|}
\hline Name & Gender & Race/Ethnicity & $\begin{array}{c}\text { Undergraduate } \\
\text { Major(s) and Credential }\end{array}$ & Prior Work Experience \\
\hline Arnold & M & Korean American & Geological Sciences & $\begin{array}{l}\text { Lab technician, assistant field } \\
\text { geologist }\end{array}$ \\
\hline Bo & M & European American & $\begin{array}{l}\text { Electrical Engineering } \\
\text { and Physics }\end{array}$ & $\begin{array}{l}\text { Staff at campus learning center, } \\
\text { private math tutor }\end{array}$ \\
\hline Donny & M & European American & Geological Sciences & $\begin{array}{l}\text { Variety of odd jobs, including } \\
\text { substitute teaching }\end{array}$ \\
\hline Jim & M & European American & Anthropology & None \\
\hline Joe & M & European American & Biopsychology & Laboratory research assistant \\
\hline Reggie & M & Latino & Chemistry & Chemist \\
\hline Samantha & $\mathrm{F}$ & Japanese American & $\begin{array}{l}\text { Geological Sciences } \\
\text { and Teaching } \\
\text { Credential }\end{array}$ & $\begin{array}{l}\text { Middle school science teacher } \\
\quad(1 \text { year })\end{array}$ \\
\hline Travis & M & European American & $\begin{array}{l}\text { Physics and Teaching } \\
\text { Credential }\end{array}$ & $\begin{array}{l}\text { High school physics teacher } \\
\text { (3 years) }\end{array}$ \\
\hline
\end{tabular}


teaching science full-time at a middle school and was now in her second year of a masters degree program in science education. Joe held an undergraduate degree in biopsychology and had worked for 2 years as a research assistant before pursuing his credential. Donny had majored in the geological sciences and had worked a variety of odd jobs, including substitute teaching, in the 2 years between degree programs. Bo held a double major in electrical engineering and physics. In the 5 years between graduating and enrolling in teacher education, he had been employed in the campus learning center and as a private math tutor. Travis had graduated with a degree in physics and a teaching credential in math and science from an Ivy League college the same year as Bo. He had taught for 1 year at an international school in the Philippines and for 2 years at a girls' boarding school in Virginia before coming to California to earn his masters degree. Like Travis, Reggie was also originally from the Northeast. He had graduated from a small college with a degree in chemistry and had worked as a chemist in a local pharmaceutical and medical device company for the past 5 years.

As with our participants, we thought it important to situate ourselves within the research process (Barton, 1998; Bloor, 1976; Kelly, Chen, \& Crawford, 1998; Rodriguez, 1998). The first author, Julie Bianchini, is an Italian American woman and assistant professor of science education. She has 9 years of teaching experience: 2 as a high school science teacher and 7 as a science teacher educator. She regularly teaches the nature of science course under investigation here and participated in both the collection and analysis of data for this study. The second author, Eric Solomon, is a European American man. He holds a masters degree in marine biology and is a doctoral candidate in science education. The second author neither participated in the course nor collected data; rather, he entered the research project during its analysis phase.

\section{Data Collection and Analysis}

To learn how beginning teachers understood ideas found at the intersection of descriptions of science and issues of equity, as well as to identify ways to improve the activities and assignments of her course, the teacher educator used two video cameras to document each 3-hour class session. When beginning teachers moved from whole class to small group activities, cameras were repositioned to capture individual groups' work. Once data collection was complete, researchers created a series of event maps from the videotaped instruction. An event map represents the phases of activity constructed by participants as they talk and work; it notes how time was spent by participants, for what purpose, under what conditions, and with what outcomes (Green \& Meyer, 1991; Santa Barbara Classroom Discourse Group, 1992). An event (e.g., a class session) refers to a bounded set of coordinated actions around a particular topic and purpose; it is composed of phases of activity. A phase of activity (e.g., a small group activity within a session) marks the ebb and flow of a concerted and coordinated action among participants. It reflects a group's common focus and is marked by members' discursive and contextual cues. Besides an event and phases, event maps for this study documented sequence units and summaries of participants' spoken discourse. We used these maps for sampling purposes, to identify phases of activity where beginning teachers connected the nature of science to equity concerns. Detailed transcripts were then made of those marked activity segments. All told, over 14 hours of videotape were transcribed in full. In our Results section, we note the date and class time, in parentheses, for each transcript excerpt used.

The contents of these verbatim transcripts were then sorted using a three-tiered coding scheme, one tier for each set of research questions posed. This process of code construction and pattern detection was iterative (Strauss, 1987). Researchers coded the transcript data together; any disagreements were discussed thoroughly and decided ultimately by consensus. Our first tier of codes focused on beginning teachers' views of science and ways to represent science to all 
students. Three substantive domains (see Spradley, 1980) and then subcategories within each emerged organically from classroom conversations: beginning teachers' views of science as situated in larger social, cultural, and historical contexts; their understanding of the need to broaden students' conceptions of scientists; and their debates about what knowledge and practices they should count as science. Subcategories under conceptions of scientists, for example, included past and present barriers to science faced by members of underrepresented groups; stereotypes of scientists as White men and the need for diverse role models; and connections between conceptions of who scientists are and what science is. Subcategories under the domain regarding what should count as science included criteria for separating science from other disciplines; the mis/use of the label science to mark all cultures' ways of understanding the natural world; and the challenges of defining science as multicultural in secondary classroom settings.

To craft our second tier of codes, the grounds beginning teachers offered for their views, we returned to our conceptual frame. We decided to organize beginning teachers' grounds for views in the same way that we had presented our discussions of science and teacher learning. We thus sorted transcript segments into one of three domains: personal, social, and political. We defined grounds within the personal domain to include beginning teachers' own experiences in school and science, with family and friends. Social domain grounds encompassed ideas connected with teacher and student interactions, conceptions of student learning, and examples of curricular and instructional strategies. Grounds within the political domain included discussions of school and science as institutions, social and cultural norms and beliefs such as racism and sexism, and broad social movements or coordinated calls to action.

In our final coding tier, we examined how grounds for views shaped beginning science teachers' attempts to understand, negotiate, and reach consensus on ideas and strategies found at the intersection of descriptions of science and issues of equity and diversity. We grouped conversations identified in Tiers 1 and 2 into one of three domains: conversations in which beginning teachers readily adopted and expanded upon ideas presented in class; ones in which they raised questions or concerns about course purpose, content, or strategies; and ones in which they provided their own insights into the challenges of teaching science in equitable and diverse ways. To best learn from our participants about how to improve science teacher preparation, to treat these beginning teachers as critical friends (see Richmond et al., 1998), we decided to limit our analysis in this third tier to the second domain, on questions posed and concerns raised by beginning teachers during small group and whole class discussions. We present findings that cut across our three tiers of codes below.

\section{Beginning Teachers' Views: Questions Raised and Grounds Offered}

Through qualitative analysis of classroom interactions, we sought to understand beginning science teachers' successes and struggles in discussing, negotiating, and attempting to reach consensus on ideas located at the intersection of descriptions of science and recommendations for an equitable and excellent science education. We used the first and second tiers of codes to organize the presentation of our results, pairing one domain on views of science offered by beginning teachers with one on grounds for views maintained. Views and grounds were paired because participants rarely moved across personal, social, and political explanations within a given discussion about science or ways to represent science to all; such pairings allowed us to examine both the views beginning teachers held, and the personal, social, and political arguments they used to support them. Thus, we present how beginning teachers' questions related to science as socially, culturally, and historically situated were influenced by their personal experiences; how their discussions of underrepresentation in scientific professions were informed by their 
understanding of teaching and learning as co-constructed activities; and how their debates about what they thought should count as modern science were shaped by conceptions of politics, power, and authority.

\section{How Is Science Situated in Society? Responses Grounded in Personal Experience}

The beginning science teachers in our study explored ways situating scientific activity within its social, cultural, and historical contexts could be used to address issues of equity and diversity in science education. They discussed how gender and racial inequities both constrained who was allowed to enter the scientific community and the kinds of scientific ideas constructed by its members. They also debated how best to teach science in context so as to interest and excite students traditionally positioned on the margins of the science classroom. To make visible beginning teachers' use of personal experiences to support their views of science and how to represent science to all, we present one small group's deliberations over the labeling as feminist instruction that connects scientific concepts and processes with their cultural, economic, and environmental contexts.

In a second activity conducted during Week 8 of class, beginning teachers first moved into small groups to develop a lesson that addressed science as situated activity and then returned to the whole class setting to share their work with peers. The geology group of Travis, Donny, and Arnold began their lesson development process by discussing an article by feminist science educator Maralee Mayberry (1998), as well as by reviewing several of her geology units from the Promise curriculum (Mayberry \& Rees, 1998). Examination of Mayberry's vision for a feminist science education sparked a lengthy debate over "the word feminism" and "what this all [teaching science as a situated activity] has to do with feminism" (11.23.2:34). Each beginning teacher drew from personal experiences to make sense of Mayberry's argument that representations of science as embedded in larger social and economic contexts-without explicit ties to women or ethnic minorities, racism or sexism-should be linked to feminism and to efforts to help students from underrepresented groups succeed in science. Arnold and Travis explained that their own experiences made them question Mayberry's recommendations for curricular and instructional transformation. Donny, in contrast, saw Mayberry's arguments as resonating with feminist ideas learned in childhood; he did not share Arnold and Travis's confusion or concern.

Arnold explained first to his small group and later to the whole class that he viewed Mayberry's approach to science education as humanist rather than feminist because it appealed to all students irrespective of their ethnicity or gender. He asked how Mayberry could label the teaching of geology concepts tied to oil exploration, capitalism, and environmental issues as feminist if women's interests and experiences were not explicitly addressed. Why did Mayberry claim that engaging students in interdisciplinary activities would benefit girls and ethnic minorities in particular? Was not feminism concerned primarily with the roles and rights of women and girls (11.23.2:39)? Arnold drew from his prior experiences as a professional geologist to critique Mayberry's recommendations for addressing the needs and interests of members of underrepresented groups and to craft one of his own. Rather than connecting science with environmental issues and capitalist greed, to better promote interest and action among girls and ethnic minorities, Arnold suggested assigning such students to positions of authority in roleplaying activities such as Mayberry's oil exploration game.

To me, I would say, "Who is going to play what role [in the oil exploration game designed by Mayberry]?" If we're going to do the activity, we need a field geologist, an economy person, the people who organize equipment. And I would try to give a female [or] minority 
those kinds of roles. Like, most field geologists are males. Even the higher ups, the decision makers, they are mostly guys too. They tell the person, "Go ahead and drill there." So you have to give women some power, that kind of thing, decision-making power. From my experience working in the industry ... I only saw one geologist who was a woman. Rest were all dudes. One minority. It was me. (11.23.2:16)

Readers should note that Arnold's suggestion of placing underrepresented students in positions of authority-facilitating their voice and valuing their perspective-is routinely recommended by feminist science educators. Of course, Mayberry's call to connect science to larger contexts is also commonly heard in feminist science education circles. It is seen as a way to empower members of underrepresented groups to pose their own questions, draw from personal experiences, and become critical thinkers [see Rosser (1997), Middlecamp and Subramaniam (1999), and Women and Scientific Literacy (1999) for further discussion]. Unfortunately, the merits of both Arnold and Mayberry's recommendations and the possible connections between them were not pursued in either small group or whole class settings. The instructor now recognizes this as a missed opportunity to pursue deeper, more connected understandings of science and ways to represent science to all with her beginning teachers.

Travis, at least initially, shared with Arnold the view that Mayberry's curricular and instructional recommendations should not be considered feminist, but for reasons drawn from his prior experiences as an undergraduate rather than as a scientist. Like Arnold, Travis thought a feminist science education should explicitly and directly address the interests, rights, and responsibilities of women and girls. He expressed concern that if examining the dangers of capitalism and the threats of environmental degradation in a geology course could be labeled feminist (he associated feminism exclusively with women), the promotion of greed and the continued search for oil must by necessity be "masculinist" (associated with men) (11.23.2:00). Travis explained that some of his reluctance in recognizing Mayberry's suggestions as feminist was shaped by his experiences with the women's movement in college, by seeing feminist activities as explicitly for women and against men.

Travis: Right. I'm caught up with the word feminism. I think maybe you [Arnold] are too. The point [Mayberry makes] is just science education would be better if we included these other things [discussions of science as tied to larger social and environmental concerns]. I certainly agree with that. The word feminism, I have connotations from college...

Arnold: Yeah.

Donny: NOW [National Organization of Women] banners.

Travis: Yeah, there was some outrageous stuff in school that I am reacting to. But everything [our instructor] said makes sense to me in terms of [what Mayberry is trying to accomplish].

Arnold: It makes sense if you just take out the word feminism.

Travis: Yeah, so just take it out, I think.

By the end of this small group task, Travis had moved away from his view that a feminist science education must explicitly examine the lives and interests of women; across our three 
vignettes this was the only instance in which a beginning teacher changed his or her view. The instructor, Julie, interrupted the small group to move discussion of grounds for views from the personal to the political. She provided a short history of the feminist movement and countered Travis's claim that feminism was anti-men. [Harding (1991, pp. 127-128), for example, explained that feminism is neither a campaign against men nor a label to which one is born. Some men are feminists and some women are not.] During group presentations to the whole class, then, Travis stated that he had come to see how activities that made "connections to society and ethics" could be considered feminist, did not necessarily blame men for current evils, and thus, should be used to "include girls and include women" in science (11.23.2:36).

\begin{abstract}
And what Arnold and I were both reacting to was [Mayberry's suggestions] seemed like more that was a good way to teach. And it had nothing to do with girls. Which [the instructor] was saying, "That's what feminism is." And that's what Donny was saying. We [Arnold and I] kind of kept having this hangup about feminism has to do with girls. And I don't so much anymore. (11.23.2:38)
\end{abstract}

Arguments made by his instructor and by Donny about the purpose and form of the feminist movement had prompted Travis to reconsider his views and the grounds for them.

Donny, as stated above, did not share Travis and Arnold's confusion over or concern with Mayberry's use of the term feminism. For Donny, "feminism doesn't just apply to girls and women" (11.23.2:03) nor should "feminism [be seen] as the opposite of "masculinism", (11.23.1:53). Donny felt comfortable supporting feminist ideas because he had learned about this political movement years ago from his stepmother.

See, I didn't struggle with that word [feminism] as much because the word was first introduced to me by my stepmother, when I was a little kid. And she, basically, it was presented to me like feminism is humanism, you know. What's best for. What we're fighting for are the rights of women. And, you know, so it's to benefit women, but it's to benefit society at large [too]. (11.23.2:39)

Like Travis and Arnold, Donny used personal experience to support his view, in this case that Mayberry's representation of science as situated activity indeed held promise for a more equitable science education.

\title{
How Broaden Notions of Who Does Science? Considering the Social Dimension of Teaching and Learning
}

A second aspect of the nature of science beginning teachers examined centered on the question of how to broaden students' notions of who does science. Teacher participants agreed that stereotypes of White men experimenting in laboratories should be replaced with views of scientists as diverse in gender and ethnicity conducting a wide range of activities. Teacher learners achieved less consensus, however, on the costs and benefits of explaining to students why women and ethnic minorities have been and remain underrepresented in the sciences. Should teachers avoid presenting barriers routinely encountered by members of underrepresented groups? Should they focus instead on the successes earned by underrepresented members? One small group's discussion of how best to represent the lives and work of women and ethnic minority scientists provides an opportunity to consider the ways the social dimension of teaching and learning served as the basis for views maintained. 
During a small group activity in Week 3, Joe, Travis, and Samantha drew from articles assigned for that day, chapters by Keller (1977) and Reiss (1993), to explore the kinds of obstacles women and members of underrepresented ethnic groups encountered in the past, and the possible reasons their work went unrecognized by the rest of the scientific community. As part of their deliberations, the three debated whether to represent science as a sometimes exclusive and elitist activity to their students, for example, whether to include a class discussion about the alienation Evelyn Fox Keller experienced as a female graduate student in physics. Joe was reluctant to present Keller's story to his students on the grounds that doing so might discourage them from pursuing science as a career.

Joe: It's kind of discouraging because she even has to leave her field. [Keller transferred from physics to molecular biology to earn her doctorate.]

Travis: Yeah, she does. It's sort of a sad ending in a way.

Samantha: But she ends up happy, though, because she says she ended up at a small college [teaching molecular biology].

Joe: I just think that's kind of a weird thing to tell kids. "If you want to be a scientist, you, too, can settle for something less than you originally planned on." (10.26.1:48)

Joe presented this same argument in both small group and whole class settings.

Travis, in contrast, thought he would include stories like Keller's in his science classes; he based his decision on personal and social grounds. This was the one instance across our three vignettes in which a beginning teacher drew from more than one domain in fashioning arguments for his or her view. In his small group, Travis explained that such stories would have helped him make sense of his own feelings of alienation as a dumb jock studying physics in college. Furthermore, he thought discussion of barriers might prove helpful to students from underrepresented groups. They would realize that they are "not the first person" to experience such barriers, he elaborated.

I'm going to send a copy of [Keller's story] to some of my girls [former students] who are studying physics [in college] and just see what their reaction is. Because I think that we all have times when we feel like we're not getting it and I think it is just nice to know there's other people out there [who felt that way too]. (10.26.1:49)

Travis's latter argument, we should underscore, is similar to that of Milne (1998): A "focus on the struggles of scientists as well as on their successes," she explained, "might help students who have struggles in their own lives to identify more closely" with science (p. 184). Like Joe, Travis's view was not altered by group conversation; he presented this same view and the grounds for it to the whole class.

Samantha came down in the middle of this debate. Her view of the utility of such stories-of representing science as a difficult career to pursue for some-was also based on the expected reactions of her students, on what we are calling the social dimension of grounds for views. Both in her small group and to the whole class, Samantha explained that she would read excerpts of Keller's story in class and then invite in a recent graduate student to share her experiences in science. She wanted to make students aware of difficulties encountered by some pursuing scientific careers, but to prevent them from growing too discouraged. Samantha hoped students 
would "realize that maybe these studies [of the experiences of women scientists and scientists from underrepresented groups] aren't to be generalized to the broader area. Maybe they aren't representative of everybody's experiences, but they are experiences that have occurred, are occurring, and hopefully in the future won't be so sex biased related" (10.26.2:12). Like Travis, Samantha's reasoning can be supported by feminist science education literature. Harding (1991) argued that discussion of the structural barriers to women's participation in the sciences should be balanced with studies of women's achievements (p. 30).

This vignette differs from the other two presented here in one important respect: Each group member maintained a different view of science on similar grounds. In her feedback to the small group of Joe, Travis, and Samantha, the instructor noted that each position held merit, but did little to encourage the building toward a consensus of views or to facilitate the examination of additional grounds for them. In retrospect, we see this as another missed opportunity to deepen and broaden beginning teachers' understanding of issues found at the intersection of descriptions of science and issues of equity and diversity.

\section{What Should Count as Modern Science? Views Grounded in Politics and Power}

A third aspect of science debated among members of this learning community involved science as cultural production. Is science acultural, monocultural, or multicultural? Is it universally practiced or undertaken in different ways by different cultures? In short, what should count as modern science? To make visible beginning teachers' use of institutional structures and/ or political movements as grounds for their views of science and how to represent science to all, we present small group and whole class deliberations during Week 6 of the nature of science course. As beginning teachers worked on a multicultural continuum activity, several questioned the inclusion of indigenous knowledge systems as science on institutional or political grounds.

In Week 6 of class, students were asked to review chapters by Harding (1994), Traweek (1993), Dalmiya and Alcoff (1993), and Weatherford (1993), and then to participate in a multicultural continuum activity. The continuum spanned four positions taken by different science educators in debates over the multicultural status of science:

1. Modern or Western science is science. It is universal and acultural. Other cultures' ways of knowing are not as powerful and useful. They do not share the same history. They should not be called science.

2. Pieces of other cultures' knowledge systems parallel modern or Western science. We should recognize and give credit to those aspects of Chinese acupuncture and Andean agriculture, for example, that fit under the umbrella of science.

3. Subsuming other cultures' ways of understanding nature under the name of science continues to privilege Western values and knowledge, as well as Western science. Let's recognize other cultures' ways of knowing as equally valid as Western ways but not label them science.

4. Modern or Western science is just one of many sciences. All cultures' ways of understanding nature should be placed on an equal footing. They should all be considered sciences.

This continuum activity was developed by a colleague, Jenifer Helms, and was loosely based on James Banks's (1999) four levels of multicultural education. See Issue 1 of the 2001 volume of Science Education for a more recent presentation of diverse multicultural views.

Beginning teachers considered each statement on the continuum and placed their names on or between those positions that most closely resonated with their own views. They were then grouped 
according to their name placement: Donny and Reggie positioned themselves between Statements 2 and 3; Travis and Samantha on Statement 3; and Joe, Arnold, and Jim between Statements 3 and 4. (Bo was absent that day of class.) Once formed, each small group worked to devise a rationale for its position. The activity concluded with group presentations of arguments and a whole class discussion.

At the beginning of the multicultural continuum activity, as teacher learners placed their names on the continuum, Reggie explained that he had decided to position himself between Statements 2 and 3 on political grounds. His reluctance to viewing indigenous knowledge systems as part of science was shaped in part by concern that some science studies scholars and science educators tended to equate "Western ways of knowing" with "science." He noted that in the modern West science did not encompass all knowledge generated. "Only part of the Western knowledge system is science," he clarified. "Not everything in the Western ways of knowing is science. ... Part of Western agriculture is scientific [and part is not, for example]" (11.9.1:46). Reggie's concerns reflect those of Cohen (1994), who also warned of the dangers of treating the West as synonymous with modernity. Cohen provided a similar critique of Harding's argument, although he thought Harding acutely aware of such concerns herself. Peers did not respond to Reggie as they moved into their small groups.

Travis, who positioned himself further down on the continuum, nonetheless shared Reggie's explanation for his view of science as multicultural. During his small group's discussion, Travis questioned Harding's (1994) argument for the acceptance of Southern, Eastern, and indigenous knowledge systems as science on the grounds that Harding was perpetuating a Western view of the world, that she was presenting the West as a monolithic entity separate from diverse others and in complete alignment with the scientific worldview. For Travis, Harding's failure to acknowledge the diversity of Western ways of understanding the natural world disrupted her argument for equity and diversity across many cultures' ways of knowing. Travis first raised this issue with Samantha: "So, to me it's not so clear that Westerners all hold this objective Western way of science that we're sort of defining. A lot of people believe in ghosts, believe in God, believe in all this stuff. How does that fit in here" (11.9.1:55)?

When Julie entered the group, Travis posed these questions again: Are there other ways of knowing besides science in Western culture? Why should Eastern, Southern, and indigenous knowledge systems such as acupuncture be counted as science, he asked, whereas Western or Northern knowledge systems such as astrology or religion should not?

Travis: Here is a question that we have, that I have at least.... [W] hat is confusing to me is if we call science "ways of understanding the natural world." To me, religion is an example of a way of understanding the natural world.... I think [Harding is] attributing these non-Western ways of understanding; she wants to elevate them to the level of science. But I don't see how she's addressing the issue of Westerners who have non-Western ways of viewing the natural world. Should we call that science too? Does that make any sense?

Samantha: Like Christian Scientists.

Travis: Like Christian Scientists.

Julie: Right. Well... do you want to count other cultures' knowledge systems as science? And people can say, "Yes, we want to be ethical. We want to promote equity. We don't want to privilege Western ways of knowing." 
The instructor agreed with Travis that fashioning a satisfactory answer to the question "Is science multicultural?" was indeed a difficult task. She did not fully grasp at that time, however, Travis's critique of equating the West with science. Travis restated his point to both Samantha and the instructor.

\begin{abstract}
But, see, what bothers me I think is that ... [i]t's still like the Western perspective of saying these other non-Western cultures, we're going to elevate them. But we're not really going to elevate the nonscientific Western [ways]. Like, if someone thinks it and they're nonWestern then it deserves to get elevated to the level of science. But we're not certainly going to start teaching astrology in science class. We're not going to start telling kids that [astrology] should be considered science in the same way that Newton's laws are. But then if we're not going to do that, then it's confusing to me why we're [going to include Eastern, Southern, and indigenous ways as science]...(11.9.1:59)
\end{abstract}

This time, Samantha, rather than the instructor, responded. Samantha shared Travis's concern about how to represent science in science classrooms. Her view of indigenous knowledge systems as separate from modern science was shaped by her understanding of the organizational and political realities of schools. Samantha explained first to her small group and then to the whole class that her position on the continuum would have been different had she approached the question from her theoretical mode as a science education graduate student, rather than from her practical role as a science teacher. From the perspective of a teacher, if she "had to address this issue in terms of context of my actual teaching" (11.9.2:05), she would "acknowledge these other ways of knowing" to her students, but explain that they would not be part of "our definition of science in this classroom" (11.9.2:14).

There is no way I'm going to go in there [the science classroom] and start challenging what the textbook says.... [From] what I know of textbooks and what I have seen of them is that they represent a Western science. ... So when I choose to define science, I would probably, if I were in a classroom, stay pretty close to the textbook. And maybe as an aside point out that we do have a lot of different cultures and different cultures have different ways of doing things...(11.9.1:52)

In the classroom, Samantha clarified, because of constraints imposed by textbooks, principals, and district and state standards, she would provide her students with a traditional representation of science. [See Adams and Krockover (1997), Bianchini et al. (in press), Brickhouse and Bodner (1992), Munby, Cunningham, and Locke (2000), and Trumbull (1999) for further discussion of the ways forces outside beginning teachers-curriculum materials, course requirements, and school structures - constrain their efforts to describe science in contemporary ways or to engage students in rich and varied investigations.]

\title{
Implications for Learning to Teach Science for All
}

As stated in our Introduction, learning to view the nature of science as tied to equity concerns is a complex and challenging task. We see our study as contributing to conversations about teacher preparation through its systematic examination and analysis of beginning teachers' grounds for views. We think our analytic framework-recognition of the personal, social, and political dimensions of science, teacher learning, and grounds for views - can be usefully employed by other teacher educators interested in promoting issues of equity and diversity. We thus begin our discussion of implications by reflecting on the sometimes tenuous connections among views held 
by our teacher learner participants, grounds offered for their views, and concerns about promoting an excellent and equitable science education. We then turn to the argument that attention to the personal, social, and political dimensions of grounds for views can assist teacher learners in making more informed and reasoned decisions about which views of science and ways to represent science to all they should employ.

Much of the research investigating beginning teachers' understanding of science in interaction with issues of equity and diversity has highlighted teacher learners' resistance to ideas and strategies presented by teacher educators in their methods courses (McGinnis \& Pearsall, 1998; Richmond et al., 1998; Rodriguez, 1998; Southerland \& Gess-Newsome, 1999). In our study, however, we found the notion of resistance inadequate to describe our beginning teachers' intent and understandings. In particular, we found it difficult to label a given beginning teacher as resistant or open to issues of inclusion. Travis, for example, rejected Mayberry's vision for a feminist science education, yet understood how discussions of barriers to science might serve to encourage students usually positioned on the margins of science classrooms. Indeed, he used the same dimension of grounds for views- personal experiences—both to critique Mayberry's work and to argue for critical examination of barriers to science participation.

We also found it difficult to label a given beginning teacher's view as resistant because the grounds offered for it were often tied to goals of equity and diversity. In other words, a view one might see as narrow or naive was often supported by reasons less exclusionary than could be easily deemed resistant. Arnold, for example, disagreed with Mayberry's recommendations for a feminist science education, but on the grounds that they were inadequate for addressing the needs and interests of members of underrepresented groups. To label Arnold's decision as resistant, then, would be to ignore his intent: Arnold shared with Mayberry the goal of making science education more equitable and inclusive. Similarly, Joe expressed reluctance to teach about barriers to participation in the sciences, but because he was concerned about discouraging those very students he hoped most to reach. Even Samantha's rejection of indigenous knowledge systems as legitimate scientific practices on institutional grounds was not without foundation: Numerous studies have documented the very real obstacles to innovation routinely encountered by beginning science teachers (Adams \& Krockover, 1997; Bianchini et al., in press; Brickhouse \& Bodner, 1992; Munby et al., 2000; Trumbull, 1999).

Although we do not think beginning teachers' views of science should remain unchallenged simply because the grounds for those views align with equity goals, we do recommend their efforts to make sense of issues of equity and diversity be acknowledged and valued. In her future nature of science courses, this instructor plans to restructure small group and whole class activities so that beginning teachers have opportunities not only to reflect on their views of science in light of course readings and activities, but to consider how closely their views and grounds align with one another and with the goals of equity and diversity. In cases in which beginning teachers' intent is to promote equity, where grounds, views, and intent seem poorly aligned, the teacher educator can use grounds offered as a starting point for promoting more nuanced understandings. She can encourage beginning teachers to consider additional research and points of view, and to reconsider connections between grounds and views in light of this larger and more diverse body of scholarship. In cases in which beginning teachers point to recognized barriers to equitable educational practices, the teacher educator can validate such concerns, share examples of teachers who have successfully overcome such obstacles, and encourage teacher learners to propose additional possible innovations collectively. In either instance, more careful attention to mis/connections across beginning teachers' views, grounds, and equity concerns can be used to better nurture their interest in and understanding of scientific literacy for all students. 
In more concrete terms, returning to our Conceptual Framework, we argue that attention to personal, social, and political dimensions of descriptions of science and conceptions of how teachers learn can help highlight and make sense of their complexity. Exclusive examination of the social nature of learning or the political aspects of science, we claim, would provide a simplistic and unsatisfying picture of how one learns or of what science is. We were struck by our finding that beginning teachers rarely moved across personal, social, and political grounds in providing reasons for views maintained. In discussing connections between teaching science in context and promoting equity and diversity, for example, the small group of Donny, Arnold, and Travis voiced opinions based solely on personal grounds. Indeed, across the three vignettes presented, only one beginning teacher, Travis, considered more than one dimension (personal and social) in fashioning his position on a given aspect of science (how to represent barriers in science to students).

We suggest beginning teachers' views of science and ways to represent science to all students could become more sophisticated if they were encouraged to consider personal, social, and political grounds for a particular position. In the nature of science course under investigation here, the instructor missed several opportunities to question beginning teachers' lines of reasoning or offer insights from other dimensions of grounds for views. Just as science teachers are encouraged to slow the pace of instruction to provide students with multiple opportunities and adequate time to grasp the complexities of a particular science concept, this teacher educator needs to provide beginning teachers with additional resources and greater structure to make sense of difficult questions related to issues of equity and access in science education. Perhaps then beginning teachers could better examine how their personal experiences, conceptions of teaching and learning, and understandings of larger social and cultural forces cohere and conflict with one another. They could also more clearly see how issues of equity and diversity are multilayered, take a great deal of study and reflection, and thus, are not easily solved. They might even grow to accept a view of science tied to equity and diversity initially rejected on different grounds. By engaging in discussions across grounds for views, we think beginning teachers would make more reasoned and reflective decisions about which images of science and ways to teach science they deem useful in promoting a science education for all students.

Finally, we see engagement in teacher research itself as a way to model for beginning teachers yet another strategy for addressing issues of equity and diversity in science education. Lifelong learning is often conceptualized as a means for teachers to deepen their subject matter knowledge or to expand their pedagogical expertise (Putnam \& Borko, 2000). Teacher learning, however, can also be defined as a process of connecting to and developing greater understanding about the interests and experiences of students. This latter definition supports the goals of excellence and equity in science education because it moves students to the center and makes their lives the starting point for thinking about and fashioning instruction (Barton, 1998; Nieto, 1999). In conducting this study, the instructor attempted to learn from her students about ways she could improve her own educational practices related to issues of equity and diversity. In future courses, she intends to devote greater time and attention to sharing research methods and previous findings with her beginning teachers. She will encourage them to follow her lead-to investigate their own practice so as to learn from their students about ways to represent science in more equitable and inclusive ways. We hope other teacher educators can see themselves and their beginning teachers reflected in our descriptions and can learn from our efforts as well.

An earlier draft of this manuscript was presented at the annual meeting of the National Association for Research in Science Teaching, March 2001, St. Louis, MO. The authors thank Gregory Kelly and Christine Cunningham for their thoughtful suggestions. 


\section{Notes}

${ }^{1}$ This quote was taken from an end-of-semester interview with a preservice science teacher participating in our study. It was made in response to the interview question: How have your views about the nature of science changed as a result of your science methods and nature of science classes? The preservice teacher's name, we should note, is a pseudonym.

${ }^{2}$ The use of the terms beginning, preservice, and practicing is deliberate; these terms are used in a consistent manner throughout the article. The site of the study was a nature of science course housed within a fifth-year teacher education program. Six of the eight students in this course were indeed preservice teachers. The remaining two were practicing teachers, with 1-3 years' teaching experience in secondary science classrooms. Because all participants had no more than 3 years of teaching experience, we collectively referred to them as beginning teachers (Grossman et al., 2000; Trumbull, 1999). Individually, participants are referred to as either preservice teachers (those formally enrolled in the teacher education program) or practicing teachers (those who already have teaching credentials and full-time teaching experience).

${ }^{3}$ Beginning teachers selected their pseudonyms and provided their ethnic identities for this study.

\section{References}

Abd-El-Khalick, F. \& Lederman, N.G. (2000a). Improving science teachers' conceptions of nature of science: A critical review of the literature. International Journal of Science Education, $22,665-701$.

Abd-El-Khalick, F. \& Lederman, N.G. (2000b). The influence of history of science courses on students' views of nature of science. Journal of Research in Science Teaching, 37, 1057-1095.

Abd-El-Khalick, F., Bell, R.L., \& Lederman, N.G. (1998). The nature of science and instructional practice: Making the unnatural natural. Science Education, 82, 417-436.

Adams, P.E. \& Krockover, G.H. (1997). Beginning science teacher cognition and its origins in the preservice secondary science teacher program. Journal of Research in Science Teaching, 34, 633-653.

Aikenhead, G.S. (1997). Toward a First Nation's cross-cultural science and technology curriculum. Science Education, 81, 217-238.

Aikenhead, G.S. \& Jegede, O.J. (1999). Cross-cultural science education: A cognitive explanation of a cultural phenomenon. Journal of Research in Science Teaching, 36, 269-288.

American Association for the Advancement of Science. (1989). Science for all Americans. New York: Oxford University Press.

American Association for the Advancement of Science. (1993). Benchmarks for science literacy. New York: Oxford University Press.

Atwater, M.M. (1996). Social constructivism: Infusion into the multicultural science education research agenda. Journal of Research in Science Teaching, 33, 821-837.

Banks, J.A. (1999). An introduction to multicultural education (2nd ed.) Boston: Allyn and Bacon.

Barad, K. (1996). Meeting the universe halfway: Realism and social constructivism without contradiction. In Nelson, L.H. \& Nelson, J. (Eds.), Feminism, science, and the philosophy of science (pp. 161-194). Dordrecht, The Netherlands: Kluwer Academic.

Barton, A.C. (1998). Feminist science education. New York: Teachers College Press.

Barton, A.C. (2000). Crafting multicultural science education with preservice teachers through service-learning. Journal of Curriculum Studies, 32, 797-820.

Bell, R.L., Lederman, N.G., \& Abd-El-Khalick, F. (2000). Developing and acting upon one's conception of the nature of science: A follow-up study. Journal of Research in Science Teaching, 37, 563-581. 
Bianchini, J.A., Cavazos, L.M., \& Rivas, M. (2002). At the intersection of contemporary descriptions of science and issues of equity and diversity: Student teachers' conceptions, rationales, and instructional practices. Manuscript submitted for publication to Journal of Science Teacher Education.

Bianchini, J.A., Johnston, C.C., Oram, S.Y., \& Cavazos, L.M. (in press). Learning to teach science in contemporary and equitable ways: The successes and struggles of first-year science teachers. Science Education.

Bloor, D. (1976). Knowledge and social imagery. London: Routledge \& Kegan Paul.

Brickhouse, N.W., Dagher, Z.R., Letts, W.J., \& Shipman, H.L. (2000). Diversity of students' views about evidence, theory, and the interface between science and religion in an astronomy course. Journal of Research in Science Teaching, 37(4), 340-362.

Brickhouse, N. \& Bodner, G. (1992). The beginning science teacher: Classroom narratives of convictions and constraints. Journal of Research in Science Teaching, 29, 471-485.

Carr, W. \& Kemmis, S. (1986). Becoming critical: Education, knowledge and action research. London: Falmer Press.

Cohen, L. (1994). Whodunit? Violence and the myth of fingerprints: Comments on Harding. Configurations, 2, 343-347.

Collins, H. \& Pinch, T. (1993). The golem: What everyone should know about science. Cambridge, England: Cambridge University Press.

Costa, V. (1995). When science is "another world": Relationships between worlds of family, friends, school, and science. Science Education, 79, 313-333.

Cunningham, C.M. \& Helms, J.V. (1998). Sociology of science as a means to a more authentic, inclusive science education. Journal of Research in Science Teaching, 35, 483500 .

Dalmiya, V. \& Alcoff, L. (1993). Are “old wives' tales” justified? In Alcoff, L. \& Potter, S. (Eds.), Feminist epistemologies (pp. 217-244). New York: Routledge.

Driver, R., Asoko, H., Leach, J., Mortimer, E., \& Scott, P. (1994). Constructing scientific knowledge in the classroom. Educational Researcher, 23, 5-12.

Driver, R., Leach, J., Millar, R., \& Scott, P. (1996). Young people's images of science. Philadelphia, PA: Open University Press.

Elliott, J. (1991). Action research for educational change. Philadelphia: Open University Press.

Feiman-Nemser, S. \& Remillard, J. (1996). Perspectives on learning to teach. In Murray, F.B. (Ed.), The teacher educator's handbook: Building a knowledge base of the preparation of teachers (pp. 63-91). San Francisco: Jossey-Bass.

Green, J.L. \& Meyer, L.A. (1991). The embeddedness of reading in classroom life. In Baker, C. \& Luke, A. (Eds.), Towards a critical sociology of reading pedagogy (pp. 141-160). Philadelphia: John Benjamins.

Grossman, P., Valencia, S., Evans, K., Thompson, C., Martin, S., \& Place, N. (2000). Transitions into teaching: Learning to teach writing in teacher education and beyond. [On-line]. Available: http://cela.albany.edu/transitions/index.html.

Haraway, D.J. (1989). Primate visions: Gender, race, and nature in the world of modern science. New York: Routledge.

Haraway, D.J. (2000). How like a leaf: An interview with Thyrza Nichols Goodeve. New York: Routledge. Press.

Harding, S. (1991). Whose science? Whose knowledge? Ithaca, NY: Cornell University

Harding, S. (1994). Is science multicultural? Configurations, 2, 301-330. 
Harding, S. (1998). Is science multicultural? Bloomington, IN: Indiana University Press.

Hart, R. (1999). On the problem of Chinese science. In Biagioli, M. (Ed.), The science studies reader (pp. 189-201). New York: Routledge.

Hewson, P.W., Tabachnick, R., Zeichner, K.M., Lomker, K.B., Meyer, H., Lemberger, J., Marion, R., Park, H.-J., \& Toolin, R. (1999). Educating prospective teachers of biology: Introduction and research methods. Science Education, 83, 247-273.

Hine, D.C. (1993). Co-laborers in the work of the lord: Nineteenth-century black women physicians. In Harding, S. (Ed.), The racial economy of science (pp. 210-227). Bloomington, IN: Indiana University Press.

Hodson, D. (1999). Going beyond cultural pluralism: Science education for sociopolitical action. Science Education, 83, 775-796.

Hubbard, R. (1990). The politics of women's biology. New Brunswick, NJ: Rutgers University Press.

Jegede, O. (1997). School science and the development of scientific culture: A review of contemporary science education in Africa International Journal of Science Education, 19,1-20.

Kass-Simon, G. \& Farnes, P. (Eds.). (1990). Women of science: Righting the record. Bloomington, IN: Indiana University Press.

Keller, E.F. (1977). The anomaly of a woman in physics. In Ruddick, S. \& Daniels, P. (Eds.), Working it out (pp. 77-91). New York: Pantheon.

Keller, E.F. (1983). A feeling for the organism: The life and work of Barbara McClintock. New York: Freeman.

Keller, E.F. (1985). Reflections on gender and science. New Haven, CT: Yale University Press.

Keller, E.F. (1997). Developmental biology as a feminist cause? Osiris, 12, 16-28.

Kelly, G.J., Chen, C., \& Crawford, T. (1998). Methodological considerations for studying science-in-the-making in educational settings. Research in Science Education, 28, 23-50.

Kemmis, S. \& McTaggart, R. (1988). The action research planner (3rd ed.) Australia: Deakin University.

Knorr-Cetina, K. (1999). Epistemic cultures: How the sciences make knowledge. Cambridge, MA: Harvard University Press.

Latour, B. \& Woolgar, S. (1986). Laboratory life: The construction of scientific facts (2nd ed.) Princeton, NJ: Princeton University Press.

Lawrence, C. \& Shapin, S. (Eds.). (1998). Science incarnate. Chicago: University of Chicago Press.

Lee, O. \& Fradd, S.J. (1998). Science for all, including students from non-English language backgrounds. Educational Researcher, 27, 12-21.

Lemke, J.L. (1990). Talking science: Language, learning and values. Norwood, NJ: Ablex.

Longino, H. (1990). Science as social knowledge: Values and objectivity in scientific inquiry. Princeton, NJ: Princeton University Press.

Lynch, S.J. (2000). Equity and science education reform. Mahwah, NJ: Erlbaum.

Mayberry, M. (1998). Reproductive and resistant pedagogies: The comparative roles of collaborative learning and feminist pedagogy in science education. Journal of Research in Science Teaching, 35, 443-459.

Mayberry, M. \& Rees, M. (1998). Projects for multicultural and interdisciplinary study and education: Draft material. Las Vegas: University of Nevada, Las Vegas.

McGinn, M.K. \& Roth, W.-M. (1999). Preparing students for competent scientific practice: Implications of recent research in science and technology studies. Educational Researcher, 28, 14-24. 
McGinnis, J.R. \& Pearsall, M. (1998). Teaching elementary science methods to women: A male professor's experience from two perspectives. Journal of Research in Science Teaching, 35, 919-949.

Middlecamp, C.H. \& Subramaniam, B. (1999). What is feminist pedagogy? Useful ideas for teaching chemistry. Journal of Chemical Education, 76, 520-525.

Milne, C. (1998). Philosophically correct science stories? Examining the implications of heroic science stories for school science. Journal of Research in Science Teaching, 35, $175-187$.

Munby, H., Cunningham, M., \& Locke, C. (2000). School science culture: A case study of barriers to developing professional knowledge. Science Education, 84, 193-211.

Narayan, U. (1989). The project of feminist epistemology: perspectives from a Nonwestern feminist. In Jagger, A. \& Bordo, S. (Eds.), Gender/body/knowledge: Feminist reconstructions of being and knowing (pp. 255-269). New Brunswick, NJ: Rutgers University Press.

National Academy of Sciences. (1998). Teaching about evolution and the nature of science. Washington, DC: National Academy Press.

National Research Council. (1996). National science education standards. Washington, DC: National Academy Press.

Nieto, S. (1999). The light in their eyes: Creating multicultural learning communities. New York: Teachers College Press.

Noffke, S.E. (1997). Professional, personal, and political dimensions of action research. In Apple, M.W. (Ed.), Review of research in education (pp. 305-343). Washington, DC: American Educational Research Association.

O'Loughlin, M. (1992). Rethinking science education: Beyond Piagetian constructivism toward a sociocultural model of teaching and learning. Journal of Research in Science Teaching, 29, 791-820.

Putnam, R.T. \& Borko, H. (2000). What do new views of knowledge and thinking have to say about research on teacher learning? Educational Researcher, 29, 4-15.

Reiss, M.J. (1993). Science education for a pluralist society. Philadelphia: Open University Press.

Richmond, G., Howes, E., Kurth, L, \& Hazelwood, C. (1998). Connections and critique: Feminist pedagogy and science teacher education. Journal of Research in Science Teaching, 35, 897-918.

Rodriguez, A.J. (1998). Strategies for counterresistance: Toward sociotransformative constructivism and learning to teach science for diversity and understanding. Journal of Research in Science Teaching, 35, 589-622.

Rossiter, M.W. (1982). Women scientists in America: Struggles and strategies to 1940. Baltimore: Johns Hopkins University Press.

Rossiter, M.W. (1995). Women scientists in America: Before affirmative action, 1940-1972. Baltimore: Johns Hopkins University Press.

Rosser, S.V. (1997). Re-engineering female friendly science. New York: Teachers College Press.

Rudolph, J.L. (2000). Reconsidering the 'nature of science' as a curriculum component. Journal of Curriculum Studies, 32(3), 403-419.

Sands, A. (1993). Never meant to survive: A black woman's journey-an interview with Evelynn Hammonds. In Harding, S. (Ed.), The racial economy of science (pp. 239-248). Bloomington, IN: Indiana University Press.

Santa Barbara Classroom Discourse Group. (1992). Do you see what we see? The referential and intertextual nature of classroom life. Journal of Classroom Interaction, 27, 29-36. 
Scheich, E. (1997). Science, politics, and morality: The relationship of Lise Meitner and Elisabeth Schiemann. Osiris, 12, 143-168.

Schiebinger, L.L. (1989). The mind has no sex? Cambridge, MA: Harvard University Press.

Schiebinger, L. (1999). Has feminism changed science? Cambridge, MA: Harvard University Press.

Schon, D.A. (Ed.). (1991). The reflective turn. New York: Teachers College Press.

Shapin, S. (1996). The scientific revolution. Chicago: University of Chicago Press.

Sleeter, C.E. \& Grant, C.A. (1999). Making choices for multicultural education: Five approaches to race, class, and gender (3rd ed.). New York: John Wiley \& Sons, Inc.

Smith, M.U., Lederman, N.G., Bell, R.L., McComas, W.F., \& Clough, M.P. (1997). How great is the disagreement about the nature of science: A response to Alters. Journal of Research in Science Teaching, 34, 1101-1104.

Solomon, J. (1987). Social influences on the construction of pupil's understanding of science. Studies in Science Education, 14, 63-82.

Solomon, J. (1994). The rise and fall of constructivism. Studies in Science Education, 23, $1-19$.

Southerland, S.A. \& Gess-Newsome, J. (1999). Preservice teachers' views of inclusive science teaching as shaped by images of teaching, learning, and knowledge. Science Education, $83,131-150$.

Spanier, B. (1995). Im/partial science. Bloomington, IN: Indiana University Press.

Spradley, J.P. (1980). Participant observation. Fort Worth, TX: Harcourt Brace Jovanovich College.

Stanley, W.B. \& Brickhouse, N.W. (1994). Multiculturalism, universalism, and science education. Science Education, 87, 387-398.

Stanley, W.B. \& Brickhouse, N.W. (2001). Teaching sciences: The multicultural question revisited. Science Education, 85, 35-49.

Strauss, A.L. (1987). Qualitative analysis for social scientists. Cambridge, England: Cambridge University Press.

Stenhouse, L. (1983). Authority, education and emancipation. London: Heinemann Educational.

Traweek, S. (1993). Cultural differences in high-energy physics. In Harding, S. (Ed.), The racial economy of science (pp. 398-407). Bloomington, IN: Indiana University Press.

Trumbull, D. (1999). The new science teacher: Cultivating good practice. New York: Teachers College Press.

Tuana, N. (1995). The values of science: Empiricism from a feminist perspective. Synthese, 104, 441-461.

Vygotsky, L.S. (1978). Mind in society: The development of higher psychological processes. Cambridge, MA: Harvard University Press.

Weatherford, J. (1993). Early Andean experimental agriculture. In S. Harding (Ed.). The racial economy of science (pp. 64-77). Bloomington, IN: Indiana University Press.

Weiner, G. (1989). Professional self-knowledge versus social justice: A critical analysis of the teacher-researcher movement. British Educational Research Journal, 15, 41-51.

Whyte, W.F. (1986). Girls into science and technology. London: Routledge \& Kegan Paul.

Women and Scientific Literacy. (1999). Frequently asked questions about feminist science studies. Washington, DC: Association of American Colleges and Universities.

Zeichner, K.M. (1993). Action research: Personal renewal and social reconstruction. Educational Action Research, 1, 199-219. 